Supporting Information for

\title{
Supramolecular Hyaluronic Assembly with Aggregation-Induced Emission Mediated in Two Stages for Targeting Cell Imaging
}

Yang Yang, ${ }^{\text {a }}$ Ya-Jun Jin, ${ }^{a}$ Xin Jia, ${ }^{\text {a }}$ Shi-Kuo Lu, ${ }^{\text {a }}$ Ze-Rui Fu, ${ }^{\text {a }}$ Yu-Xi Liu, ${ }^{\text {a }}$ Yu Liu ${ }^{\text {b }}$

aSchool of Chemical Engineering and Technology, Hebei University of Technology, Tianjin, 300130, P. R. China

bDepartment of Chemistry, State Key Laboratory of Elemento-Organic Chemistry, Nankai University, Tianjin, 300071, P. R. China

${ }^{*}$ Corresponding author: yuliu@nankai.edu.cn 


\section{Experimental section}

Materials. All the chemicals were reagent-grade using in this study. $\beta$-CD was recrystallized twice from water and dried in vacuo at $90{ }^{\circ} \mathrm{C}$ for $24 \mathrm{~h}$ prior to use.

Sodium hyaluronate $\left(M_{w}=190,000\right)$ 4-hydroxybenzophenone, 1-adamantanecarbonyl chloride, triethylamine $\left(\mathrm{Et}_{3} \mathrm{~N}\right)$, titanium tetrachloride $\left(\mathrm{TiCl}_{4}\right)$ and zinc powder were purchased from commercial resources and used as received. HACD was prepared according to the reported literature procedure. ${ }^{1}$ Column chromatography was performed on 200-300 mesh silica gel.

Instruments. ${ }^{1} \mathrm{H}$ NMR spectra were recorded on Bruker AV400 instruments. Mass spectra were performed on a MALDI-TOF mode MS. High-resolution transmission electron microscope (HR-TEM) images were obtained on a Tecnai $G^{2}$ F20 microscope instrument with an accelerating voltage of $200 \mathrm{kV}$. The samples were prepared by placing a drop of solution $\left(1 \mathrm{mg} \mathrm{mL}^{-1}\right)$ on a carbon-coated copper grid and air-dried. For the atomic force microscope (AFM) measurements, a drop of sample solution was dropped onto newly clipped mica and air-dried, and then examined on AFM (Veeco Company, Multimode, NanoIIIa) in tapping mode in the air under ambient conditions. The sample solutions for DLS experiments were prepared by filtering each solution through a $450 \mathrm{~nm}$ syringe-driven filter (JET BIOFIL) into a clean scintillation vial. The samples were examined on a Brookhaven BI-200SM laser light scattering spectrometer equipped with a digital correlator (BI-9000AT) at $\lambda=636 \mathrm{~nm}$ at $25{ }^{\circ} \mathrm{C}$. All DLS measurements were performed at the scattering angle of $90^{\circ}$. The $\zeta$ potential was recorded on Nano-ZS90 (Malvern 
company) at $25^{\circ} \mathrm{C}$. XPS spectra were performed on ESCALAB 250Xi instrument. UV/vis spectra were recorded in a conventional quartz cell (light path as $1 \mathrm{~cm}$ ) by Shimadzu UV-2401PC spectrophotometer equipped with a Thermo HAAKE-SC100 temperature controller to keep the temperature at $25{ }^{\circ} \mathrm{C}$. Fluorescence spectra were measured in a conventional quartz cell at $25{ }^{\circ} \mathrm{C}$ by using an Edinburgh Analytical Instruments FL900CD spectrometer. Fluorescence lifetime and quantum yield were measured on FLS1000 spectrometer. The fluorescence confocal images were carried out on Leica TCS SP8 fluorescence microscope $\left(\lambda_{\mathrm{ex}}=330 \mathrm{~nm}, 25^{\circ} \mathrm{C}\right)$.

\section{Synthesis of 4-benzoylphenyl-adamantane-1-carboxylate}

4-Hydroxybenzophenone (1.0 g, $5.05 \mathrm{mmol})$ and 1-adamantanecarbonyl chloride (1.0 $\mathrm{g}, 5.03 \mathrm{mmol})$ were dissolved in $\mathrm{CH}_{2} \mathrm{Cl}_{2}(30 \mathrm{~mL})$, and triethylamine $\left(\mathrm{Et}_{3} \mathrm{~N}, 2 \mathrm{~mL}\right)$ was added as trapping agent for hydrogen chloride. The mixture was stirred at room temperature for $24 \mathrm{~h}$, and then the solution was washed by $0.01 \mathrm{M}$ hydrochloric acid and deionized water $(30 \mathrm{~mL} \times 3$ times $)$. The organic phase was dried by anhydrous $\mathrm{Na}_{2} \mathrm{SO}_{4}$ and then concentrated and purified by column chromatography on silica gel (dichloromethane:petroleum ether $=4: 1$ ) to obtain pure 4-benzoylphenyl-adamantane-1-carboxylate as white solid (1.22 g) in $67.3 \%$ yield. ${ }^{1} \mathrm{H}$ NMR (400 MHz, $\left.\mathrm{CDCl}_{3}, \mathrm{ppm}\right): \delta=1.74-1.81(\mathrm{~m}, 6 \mathrm{H}, \mathrm{H}$ of adamantane), 2.07-2.10 (m, 9H, H of adamantane), 7.16-7.18 (d, 2H, $J=8.6 \mathrm{~Hz}), 7.47-7.50(\mathrm{t}, 2 \mathrm{H}, J=7.6$ $\mathrm{Hz}), 7.58-7.61(\mathrm{t}, 1 \mathrm{H}, J=7.4 \mathrm{~Hz}), 7.78-7.80(\mathrm{~d}, 2 \mathrm{H}, J=7.1 \mathrm{~Hz}), 7.84-7.86(\mathrm{~d}, 2 \mathrm{H}, J=$ 8.6 Hz); $\left.{ }^{13} \mathrm{C} \mathrm{NMR} \mathrm{(100} \mathrm{MHz,} \mathrm{CDCl}_{3}, \mathrm{ppm}\right): \delta=27.8,36.4,38.7,40.9,120.7,126.6$, 
127.8, 131.3, 132.2, 140.2, 140.8, 143.3, 176.0; molecular formula: $\left[\mathrm{C}_{24} \mathrm{H}_{24} \mathrm{O}_{3}+\mathrm{H}\right]^{+}$, ESI-mass found: 361.1800 , mass required: 361.1798.

\section{Synthesis of adamantane-modified tetraphenylethene (TPE-ADA)}

4-Benzoylphenyl-adamantane-1-carboxylate $(750 \mathrm{mg}, 2 \mathrm{mmol})$ and zinc powder (600 mg, $9.2 \mathrm{mmol}$ ) in $40 \mathrm{~mL}$ THF was stirred under Ar protection in ice-salt bath. The solution was cooled down to $-5{ }^{\circ} \mathrm{C}$ for $30 \mathrm{~min}$, and then $\mathrm{TiCl}_{4}(0.5 \mathrm{~mL}, 3 \mathrm{mmol})$ was added. After that, the reaction mixture was allowed to warm till room temperature and refluxed overnight. The mixture was filtered, and the solvent of filtrate was removed under reduced pressure. The residue was re-dissolved in $50 \mathrm{~mL} \mathrm{CHCl}_{3}$, and washed by deionized water $(50 \mathrm{~mL} \times 3$ times $)$. The organic phase was dried by anhydrous $\mathrm{Na}_{2} \mathrm{SO}_{4}$ and then concentrated. The crude product was purified by column chromatography using $\mathrm{CH}_{2} \mathrm{Cl}_{2}$ /petroleum ether $(2: 1)$ as eluent to give trans-TPE-ADA as white powder in $45.2 \%$ yield $(311 \mathrm{mg})$. At the meanwhile, the cis-form of TPE-ADA was also obtained as by-product in $1.7 \%$ yield $(11.7 \mathrm{mg}) .{ }^{1} \mathrm{H}$ NMR (400 MHz, $\left.\mathrm{CDCl}_{3}, \mathrm{ppm}\right): \delta=1.75(\mathrm{~m}, 12 \mathrm{H}), 2.02-2.07(\mathrm{~m}, 18 \mathrm{H}), 6.81-6.83(\mathrm{~m}$, 4H), 7.01-7.08 (m, 14H); $\left.{ }^{13} \mathrm{C} \mathrm{NMR} \mathrm{(100MHz,} \mathrm{CDCl}_{3}, \mathrm{ppm}\right): \delta=27.6,36.1,38.5$, $40.9,121.3,128.1,129.7,131.48,132.2,134.5,137.3,154.3,175.5,195.4$; molecular formula: $\left[\mathrm{C}_{48} \mathrm{H}_{48} \mathrm{O}_{4}+\mathrm{NH}_{4}\right]^{+}$, ESI-mass found: 706.3902, mass required: 706.3891.

\section{Construction of TPE-ADA/HACD nanoparticle}

TPE-ADA (2.1 mg, $0.003 \mathrm{mmol})$ was dissolved into $60 \mu \mathrm{L}$ of DMSO under ultrasound, which was added into $1.5 \mathrm{~mL}$ PBS containing HACD (30.2 mg). The obtained aqueous solution of TPE-ADA/HACD nanoparticle (containing $2 \times 10^{-3} \mathrm{M}$ 
TPE-ADA and $4 \times 10^{-3} \mathrm{M} \beta$-CD) was ultrasonicated for $5 \mathrm{~min}$ and then stored at 4 ${ }^{\circ} \mathrm{C}$.

\section{Fluorescent confocal imaging}

At $37{ }^{\circ} \mathrm{C}$ under $5 \% \mathrm{CO}_{2}$, NIH3T3 mouse embryonic fibroblasts and PC-3 human prostatic cancer cells were cultured in the Dulbecco-modified Eagle's medium (DMEM) and 1640 medium, respectively, which were supplemented with 10\% fetal bovine serum (FBS). Then the cells were seeded on $14 \mathrm{~mm}^{2}$ cover slips placed in 6-well plates $\left(1 \times 10^{5}\right.$ cells $\mathrm{mL}^{-1}, 2 \mathrm{~mL}$ per well $)$. After $24 \mathrm{~h}$, the cells were incubated with TPE-ADA/HACD nanoparticles $\left([\right.$ TPE-ADA $\left.]=5 \times 10^{-5} \mathrm{M}\right)$ for $4 \mathrm{~h}$, then the culture medium was removed and the cells were washed with fresh PBS for 3 times, which were finally subjected to the observation by fluorescence confocal microscope.

\section{Cytotoxicity Experiments}

NIH3T3 cells and PC-3 cancer cells were cultured in DMEM and 1640 medium supplemented with $10 \%$ FBS in 96 -well plates $\left(5 \times 10^{4}\right.$ cells $\mathrm{mL}^{-1}, 100 \mu \mathrm{L}$ per well) for $24 \mathrm{~h}$ at $37{ }^{\circ} \mathrm{C}$ under $5 \% \mathrm{CO}_{2}$. Then the cells were incubated with TPE-ADA/HACD nanoparticles at different TPE-ADA concentrations $(0,2.1,6.2$, $18.5,55.5,167,500,1500 \mu \mathrm{M})$ for $24 \mathrm{~h}$ and $48 \mathrm{~h}$, respectively, the relative cellular viability was measured by standard CCK 8 assay. ${ }^{2}$ 

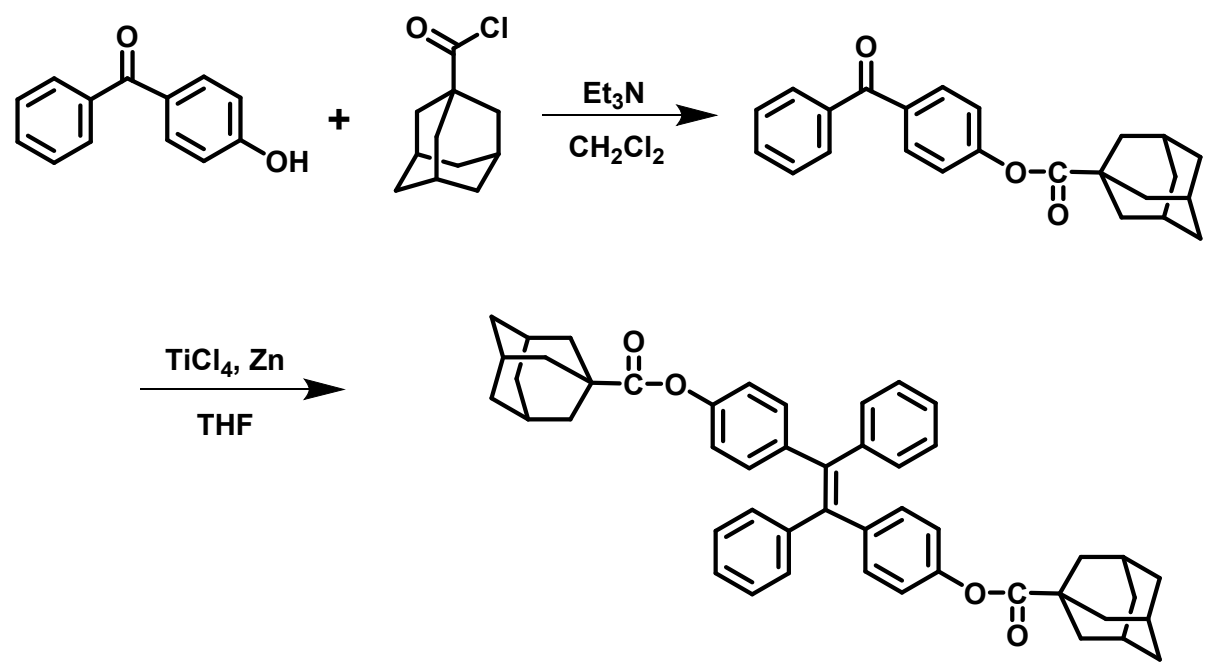

Figure S1. The synthetic route of TPE-ADA.

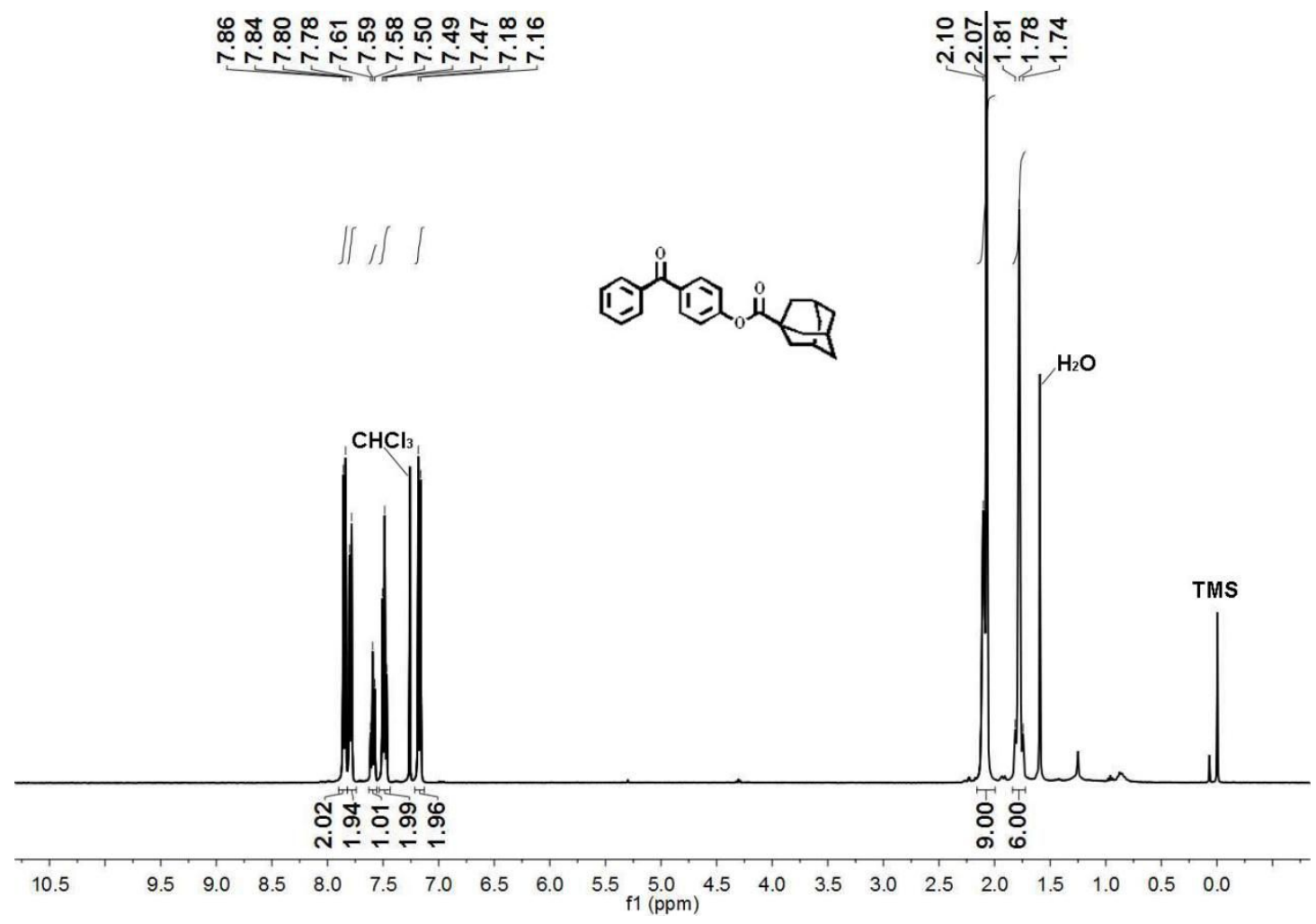

Figure $\quad$ S2. $\quad{ }^{1} \mathrm{H} \quad$ NMR $\quad\left(\begin{array}{lllll}400 & \mathrm{MHz}\end{array}\right)$ spectrum $\quad$ of 4 4-benzoylphenyl -adamantane-1-carboxylate in $\mathrm{CDCl}_{3}$ at $25^{\circ} \mathrm{C}$. 


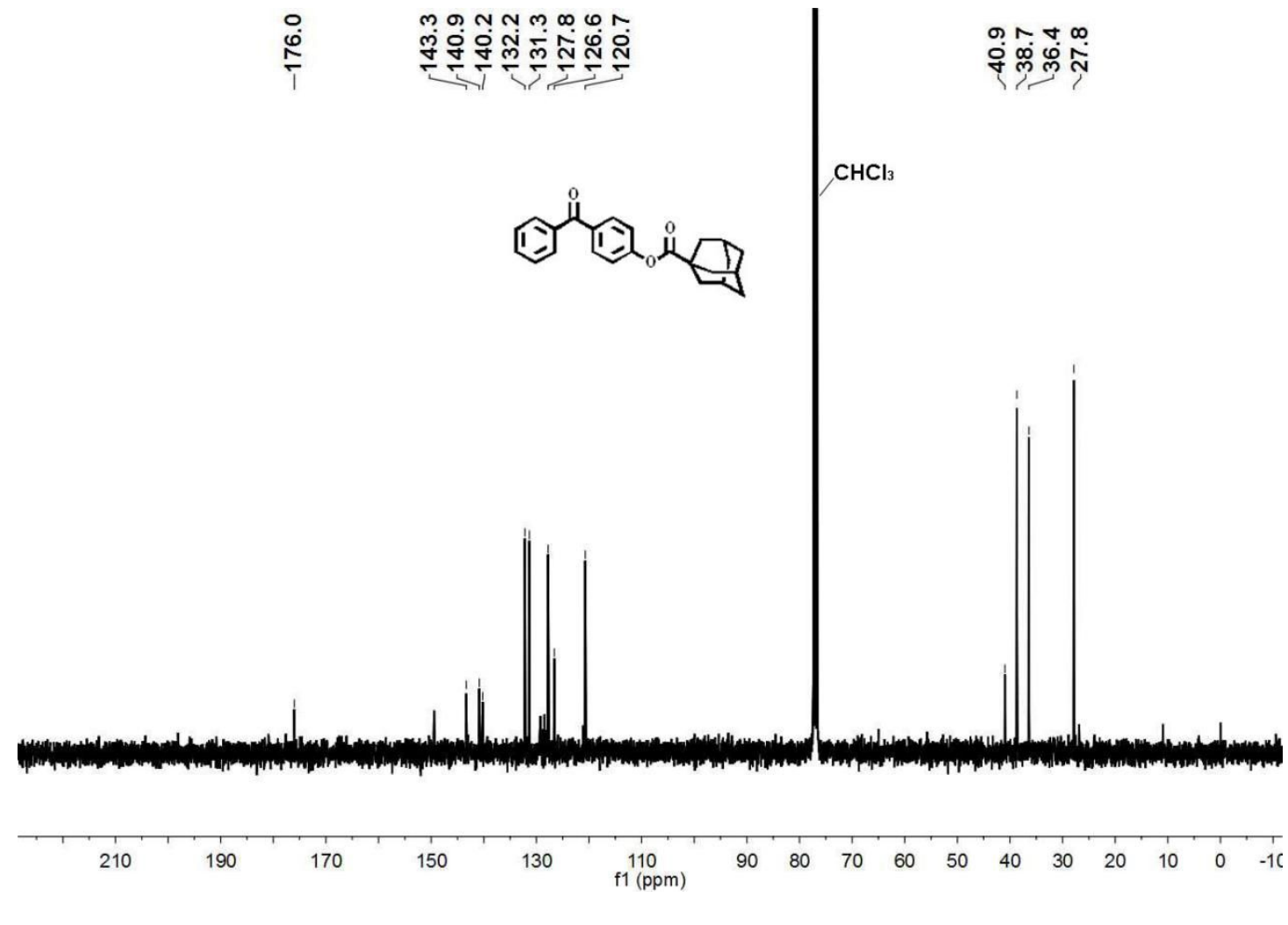

Figure $\quad$ S3. ${ }^{13} \mathrm{C} \quad$ NMR $\quad\left(\begin{array}{lllll}100 & \mathrm{MHz}\end{array}\right)$ spectrum of 4-benzoylphenyl -adamantane-1-carboxylate in $\mathrm{CDCl}_{3}$ at $25^{\circ} \mathrm{C}$.

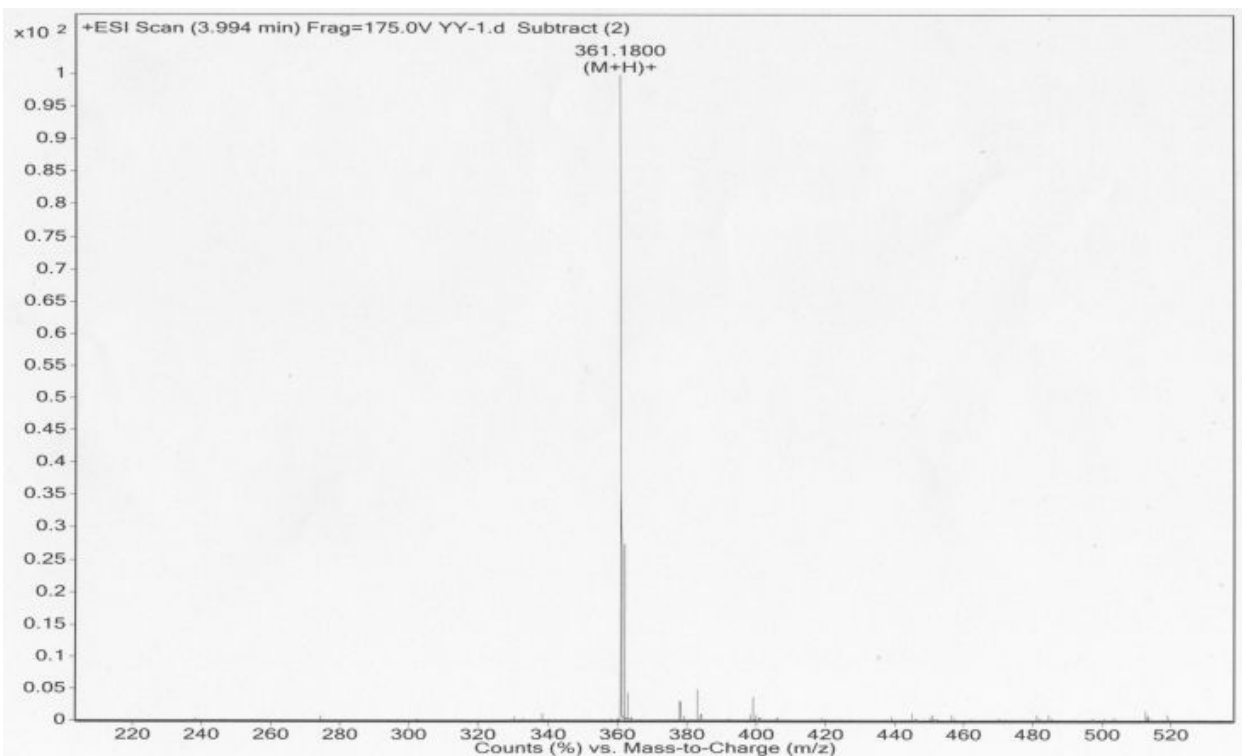

Figure S4. ESI mass spectra of 4-benzoylphenyl -adamantane-1-carboxylate 


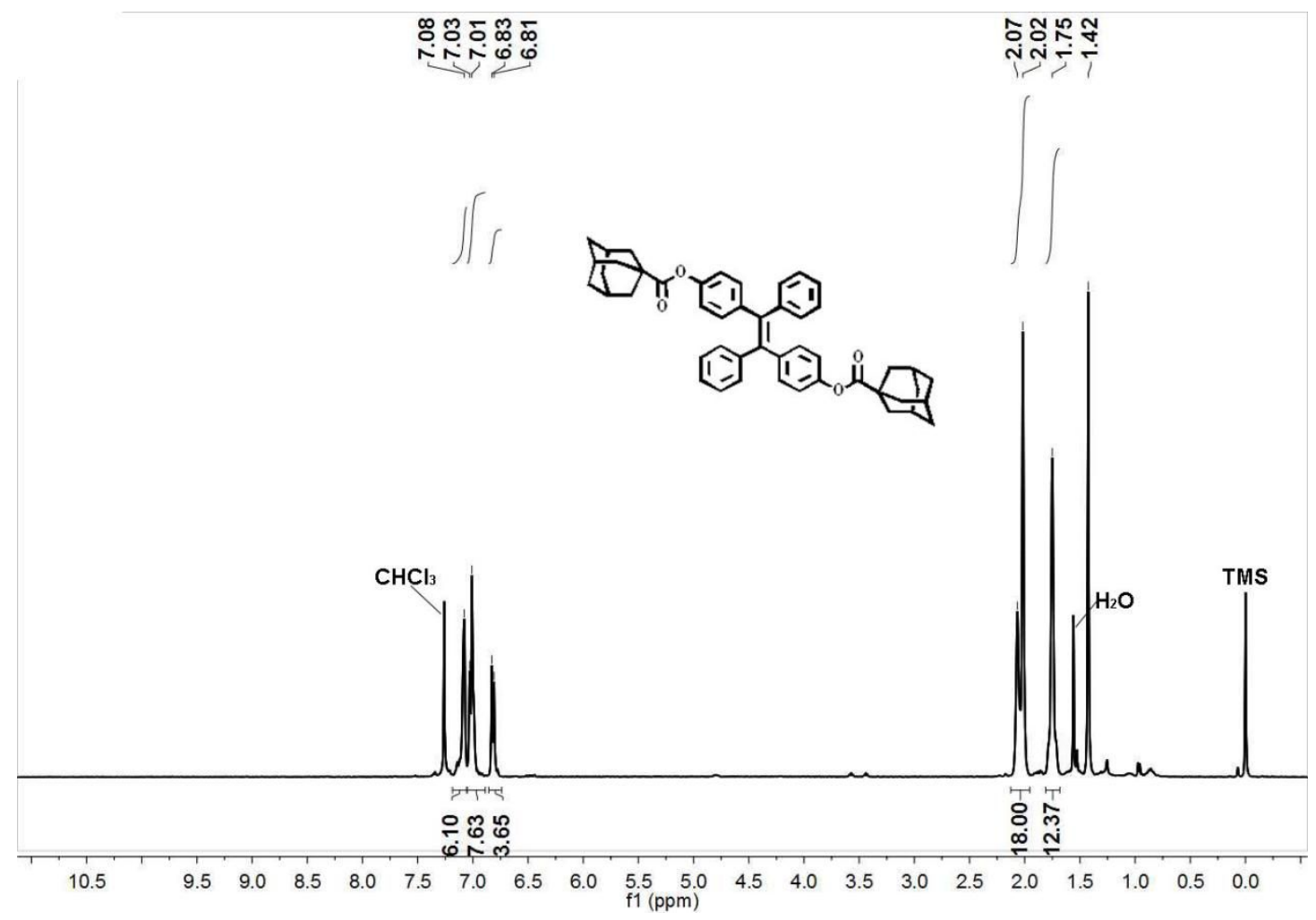

Figure S5. ${ }^{1} \mathrm{H}$ NMR $(400 \mathrm{MHz})$ spectrum of TPE-ADA in $\mathrm{CDCl}_{3}$ at $25{ }^{\circ} \mathrm{C}$.

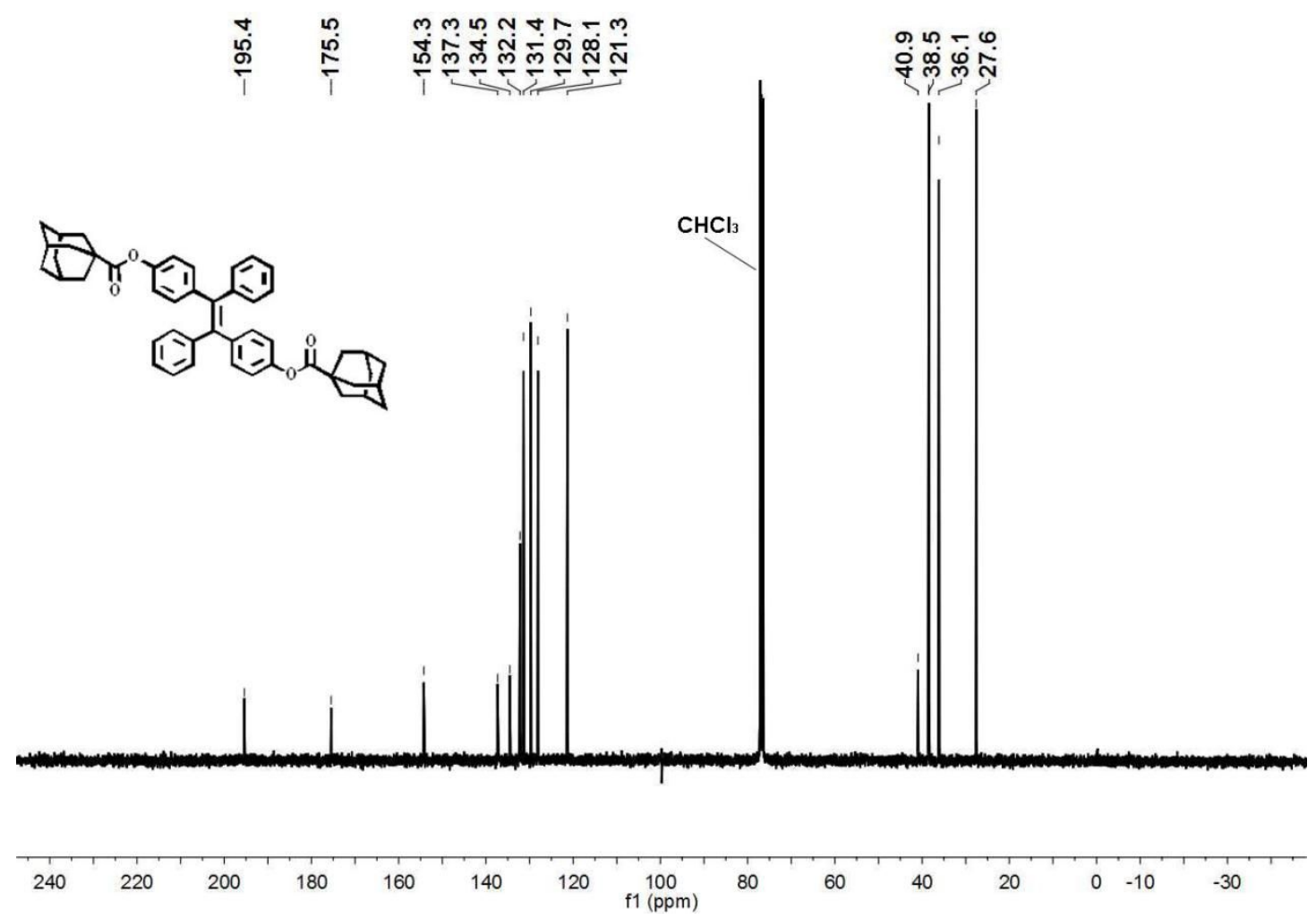

Figure S6. ${ }^{13} \mathrm{C}$ NMR $(100 \mathrm{MHz})$ spectrum of TPE-ADA in $\mathrm{CDCl}_{3}$ at $25{ }^{\circ} \mathrm{C}$. 


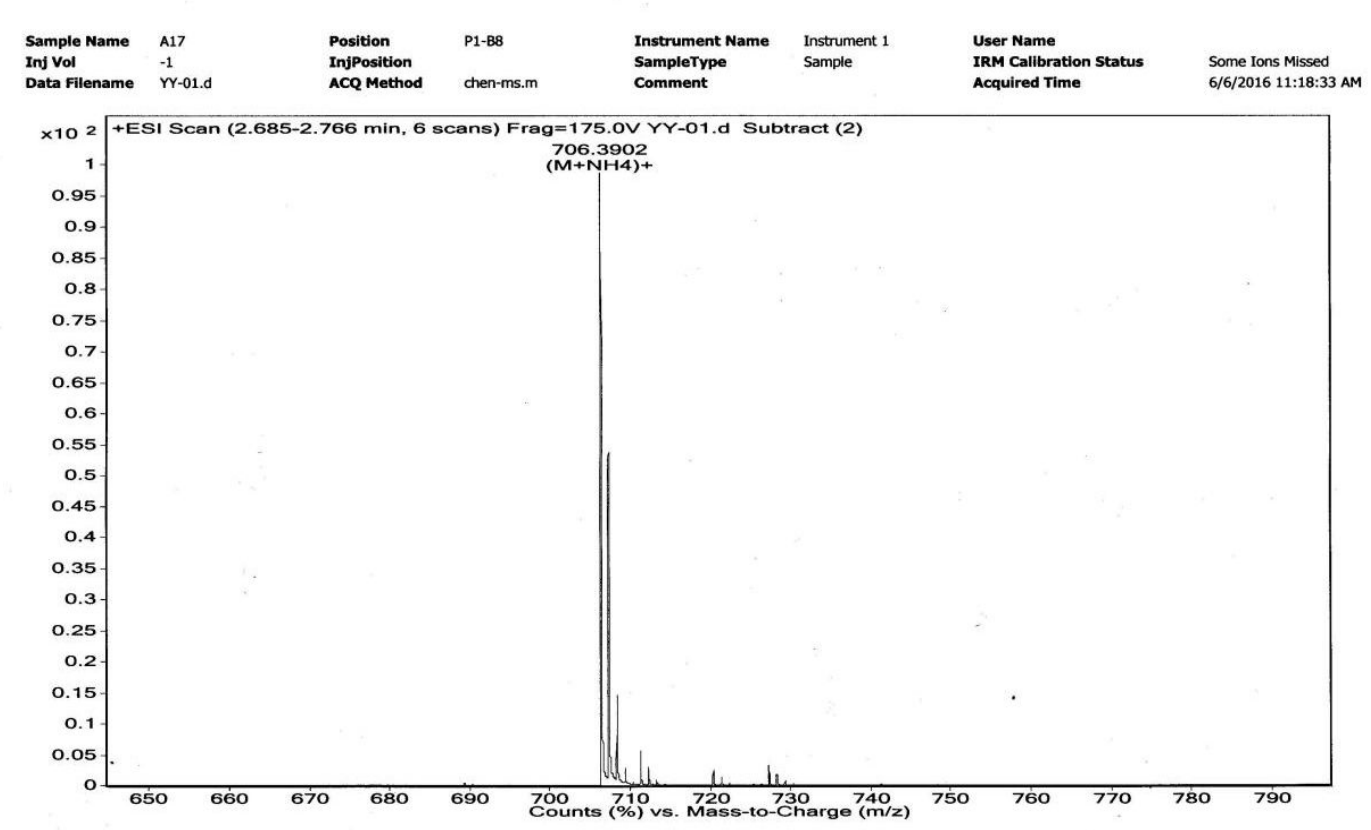

Figure S7. ESI mass spectra of TPE-ADA

(a)

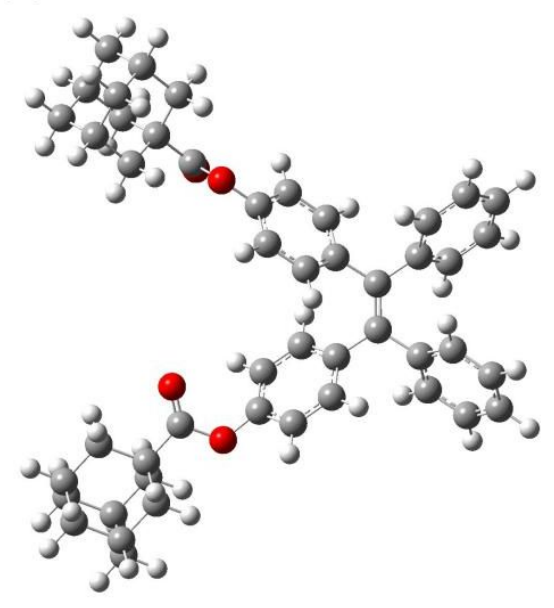

(b)

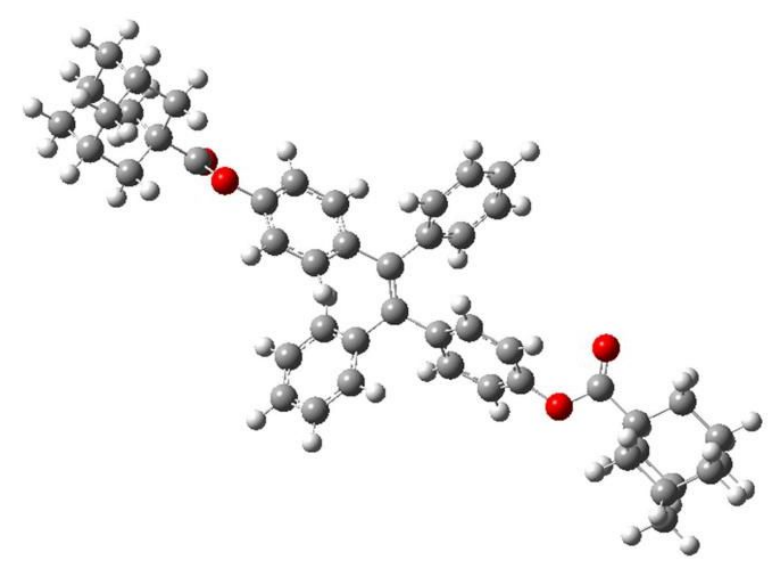

Figure S8. The theoretical simulation on dipole of (a) cis-isomer and (b) trans-isomer of TPE-ADA. 

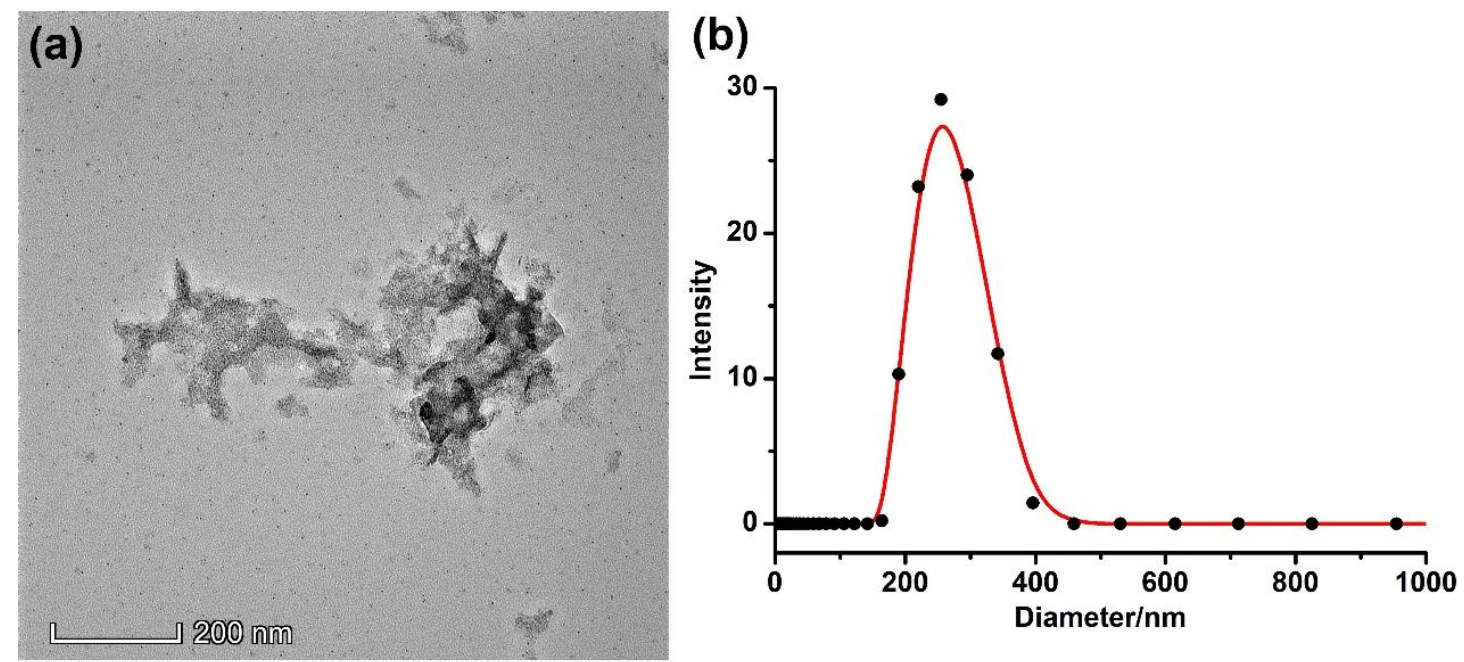

(C) ${ }_{\text {Mpe-ada (Run 5) }}^{\text {Measurement Completed }}$ Runs Completed: 5

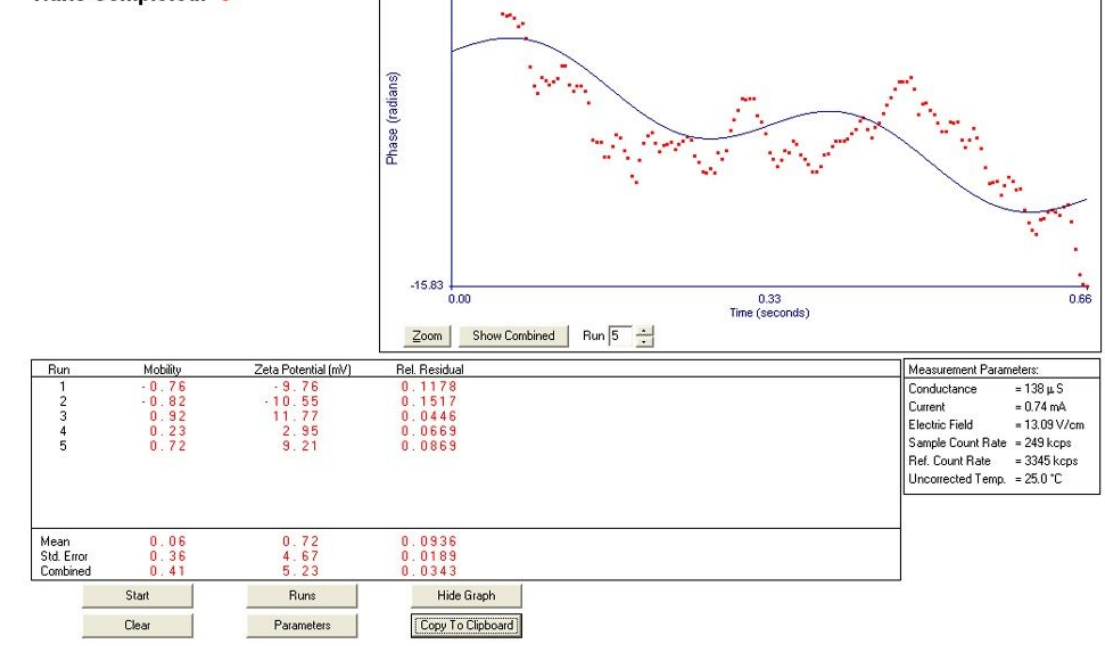

Figure S9. Typical (a) HR-TEM image, (b) DLS, and (c) $\zeta$ potential of TPE-ADA assembly. 


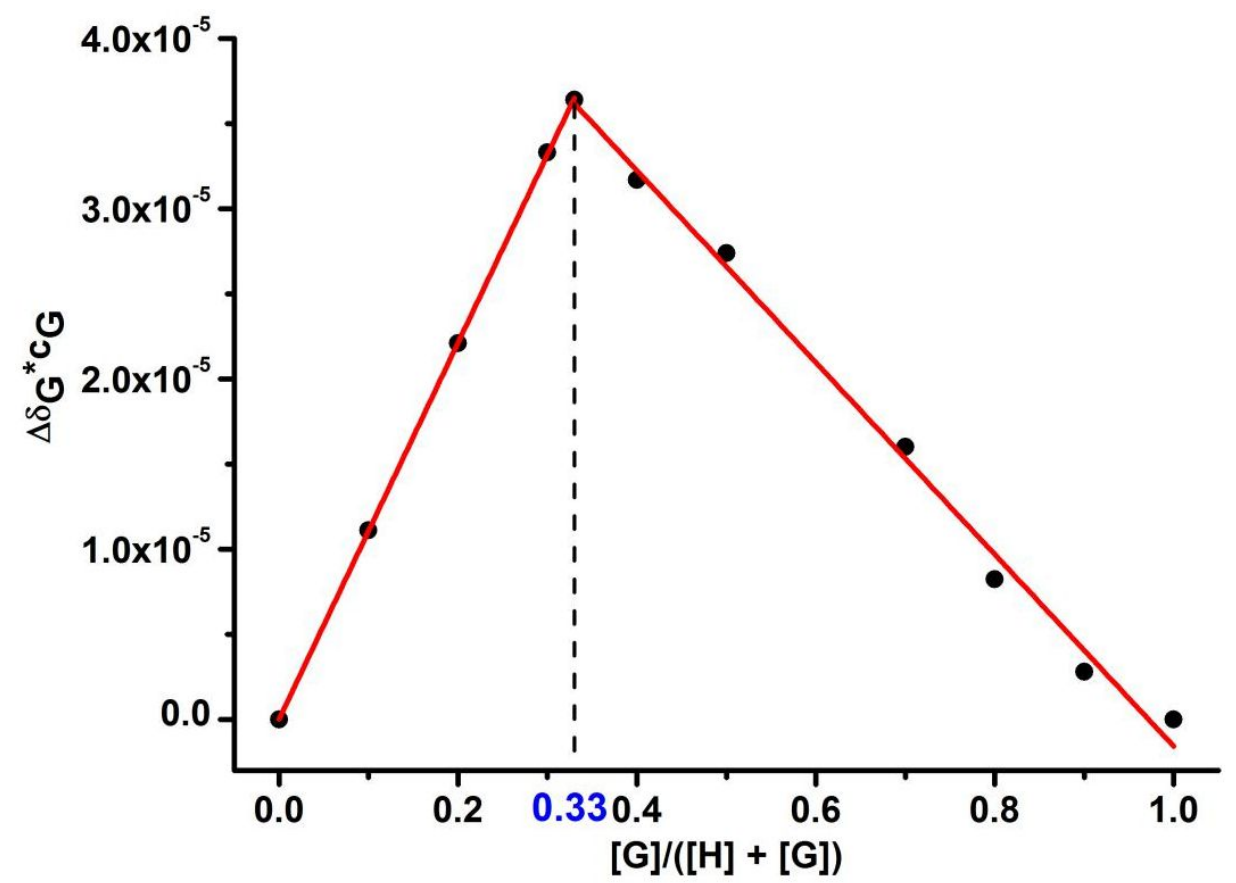

Figure S10. The Job's plot of TPE-ADA $(\mathrm{G})$ and $\beta$-CD $(\mathrm{H})([$ TPE-ADA $]+[\beta-\mathrm{CD}]=$ $1.2 \times 10^{-3} \mathrm{M}$, solvent was $\mathrm{D}_{2} \mathrm{O}$ solution containing $4 \%$ DMSO- $d_{6}$ at $25^{\circ} \mathrm{C}$ ).

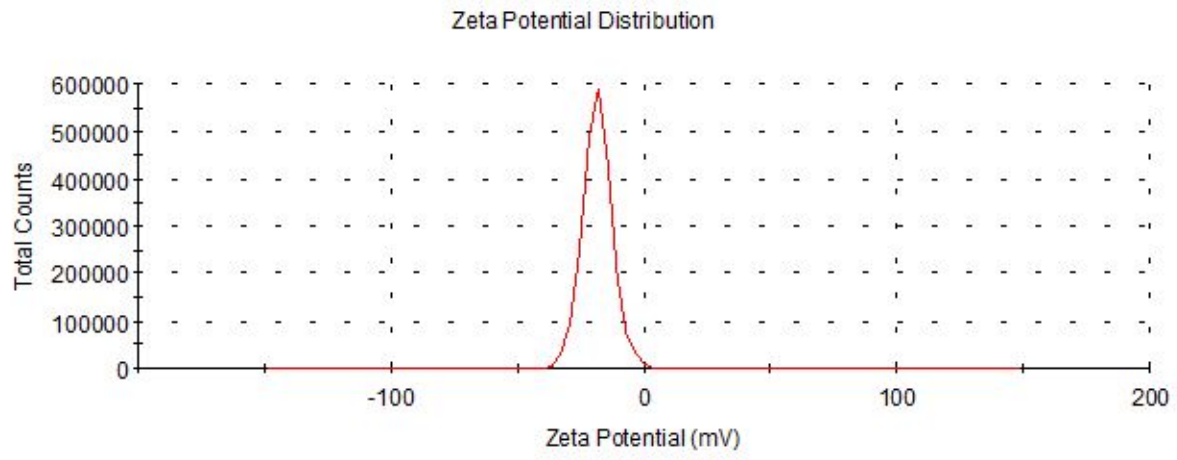

Figure S11. $\zeta$ potential result of TPE-ADA/HACD nanoparticle $([$ TPE-ADA $]=2 \times$ $10^{-4} \mathrm{M},[\mathbf{H A C D}]=5.9 \times 10^{-6} \mathrm{M}$, containing $4 \times 10^{-4} \mathrm{M} \beta$-CD, solvent was aqueous solution containing $4 \%$ DMSO at $25^{\circ} \mathrm{C}$ ). 
(a)

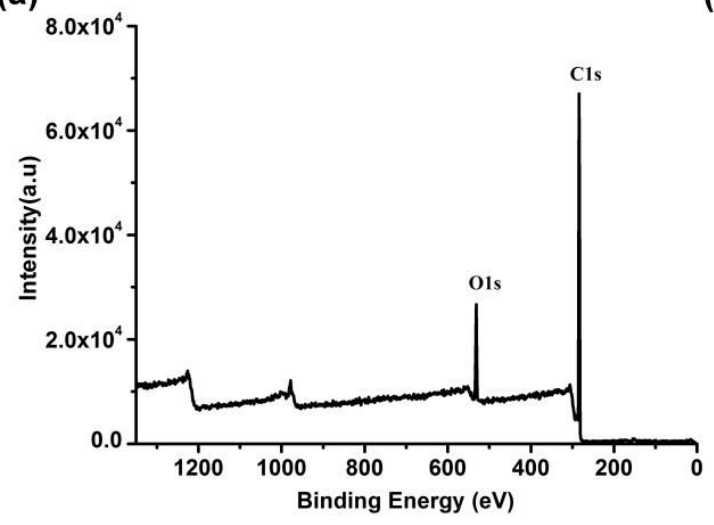

(b)

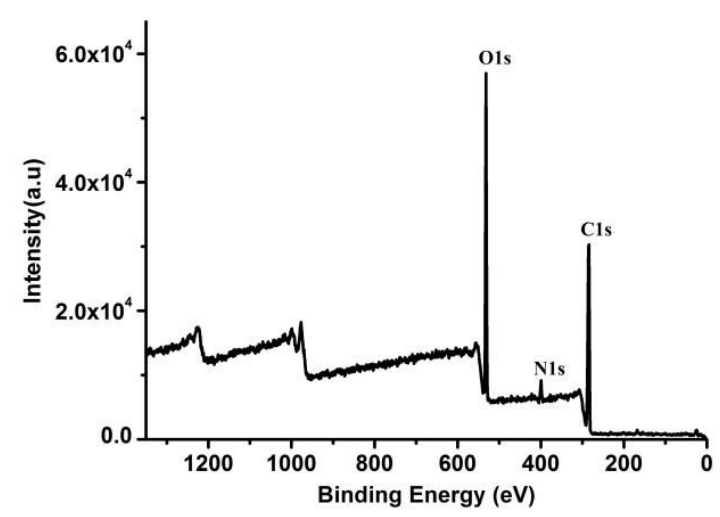

Figure S12. The XPS spectra of (a) TPE-ADA and (b) TPE-ADA/HACD.

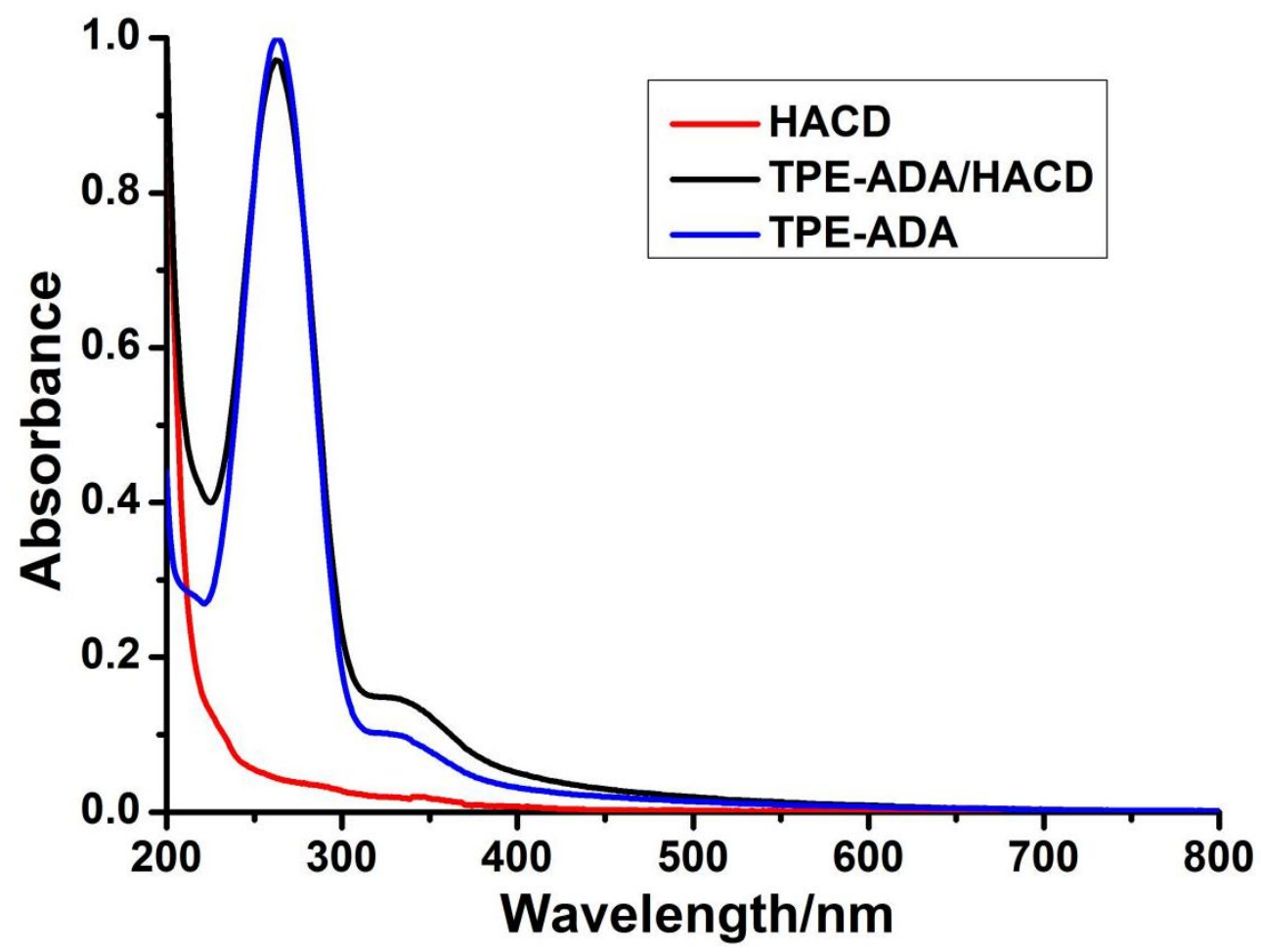

Figure S13. Normalized UV/Vis spectra of HACD, TPE-ADA, and TPE-ADA/HACD nanoparticle $\left([\right.$ TPE-ADA $]=2 \times 10^{-4} \mathrm{M},[$ HACD $]=5.9 \times 10^{-6} \mathrm{M}$, containing $4 \times 10^{-4} \mathrm{M} \beta$-CD, solvent was aqueous solution containing $4 \%$ DMSO at $\left.25^{\circ} \mathrm{C}\right)$. 


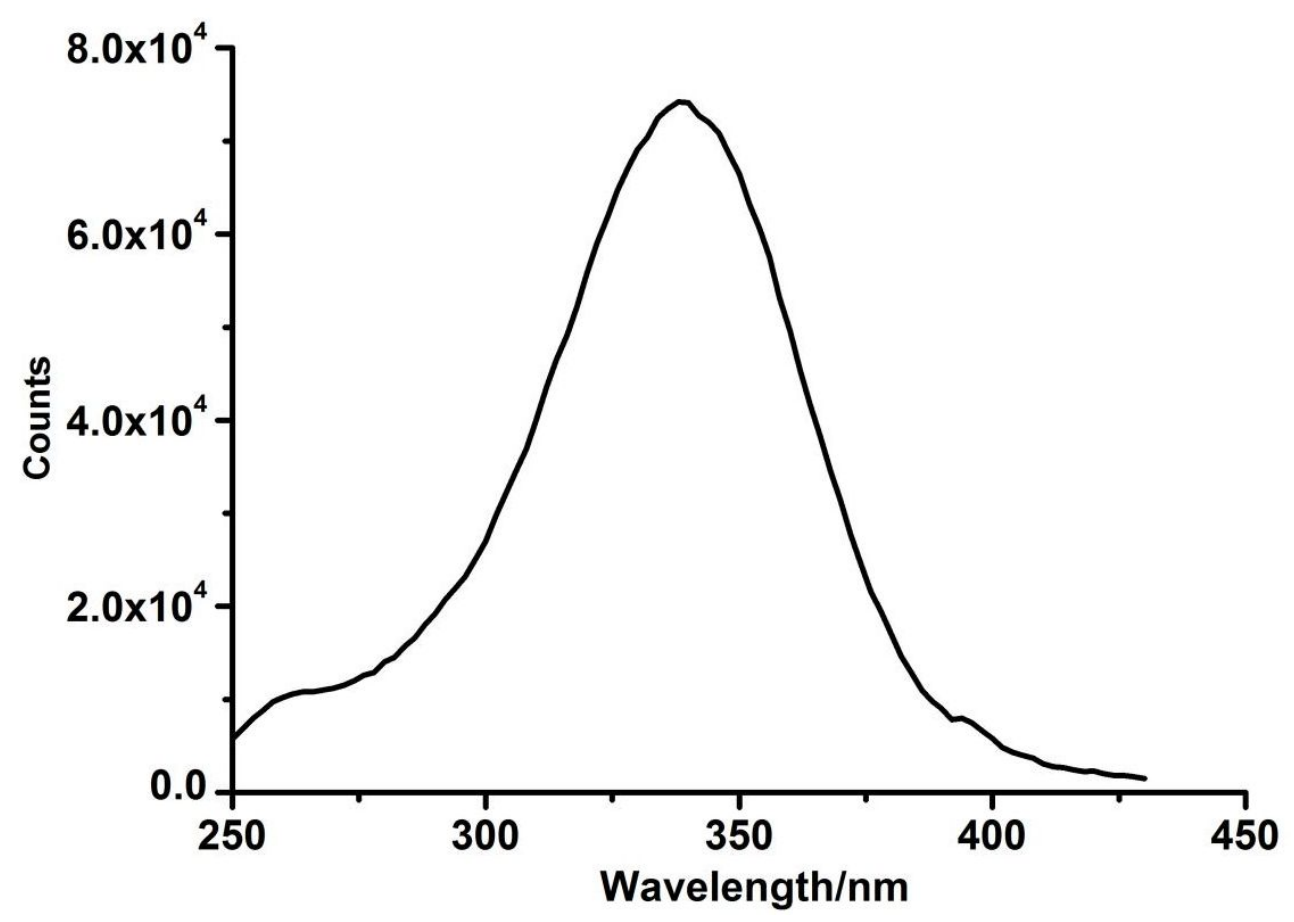

Figure S14. The fluorescence excitation spectrum of TPE-ADA $([$ TPE-ADA $]=3 \times$ $10^{-5} \mathrm{M}$, the solvent was aqueous solution containing $4 \%$ DMSO at $25^{\circ} \mathrm{C}$ ).
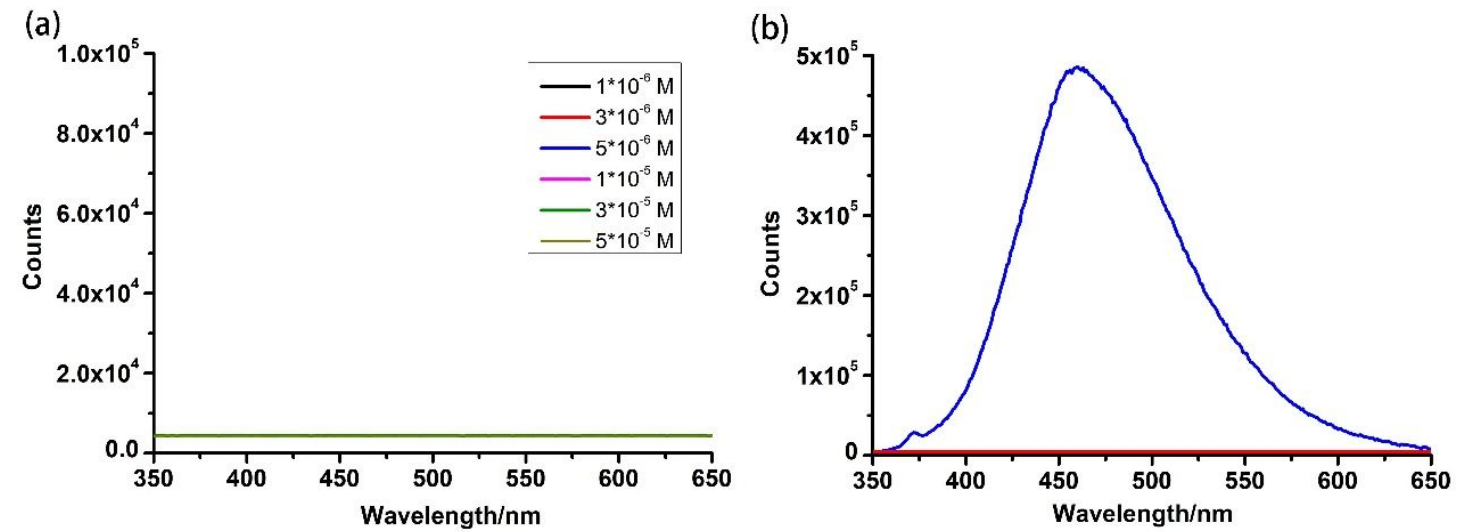

Figure S15. (a) The fluorescence of TPE-ADA with different concentrations in pure DMSO (Black: $1 \times 10^{-6} \mathrm{M}$; Red: $3 \times 10^{-6} \mathrm{M}$; Blue: $5 \times 10^{-6} \mathrm{M}$; Pink: $1 \times 10^{-5} \mathrm{M}$; Green: $3 \times 10^{-5} \mathrm{M}$; Khaki: $5 \times 10^{-5} \mathrm{M}$ ), (b) the fluorescence of TPE-ADA at concentration of $3 \times 10^{-5} \mathrm{M}$ in pure DMSO (Red) and aqueous solution containing $4 \%$ 
DMSO (Blue).

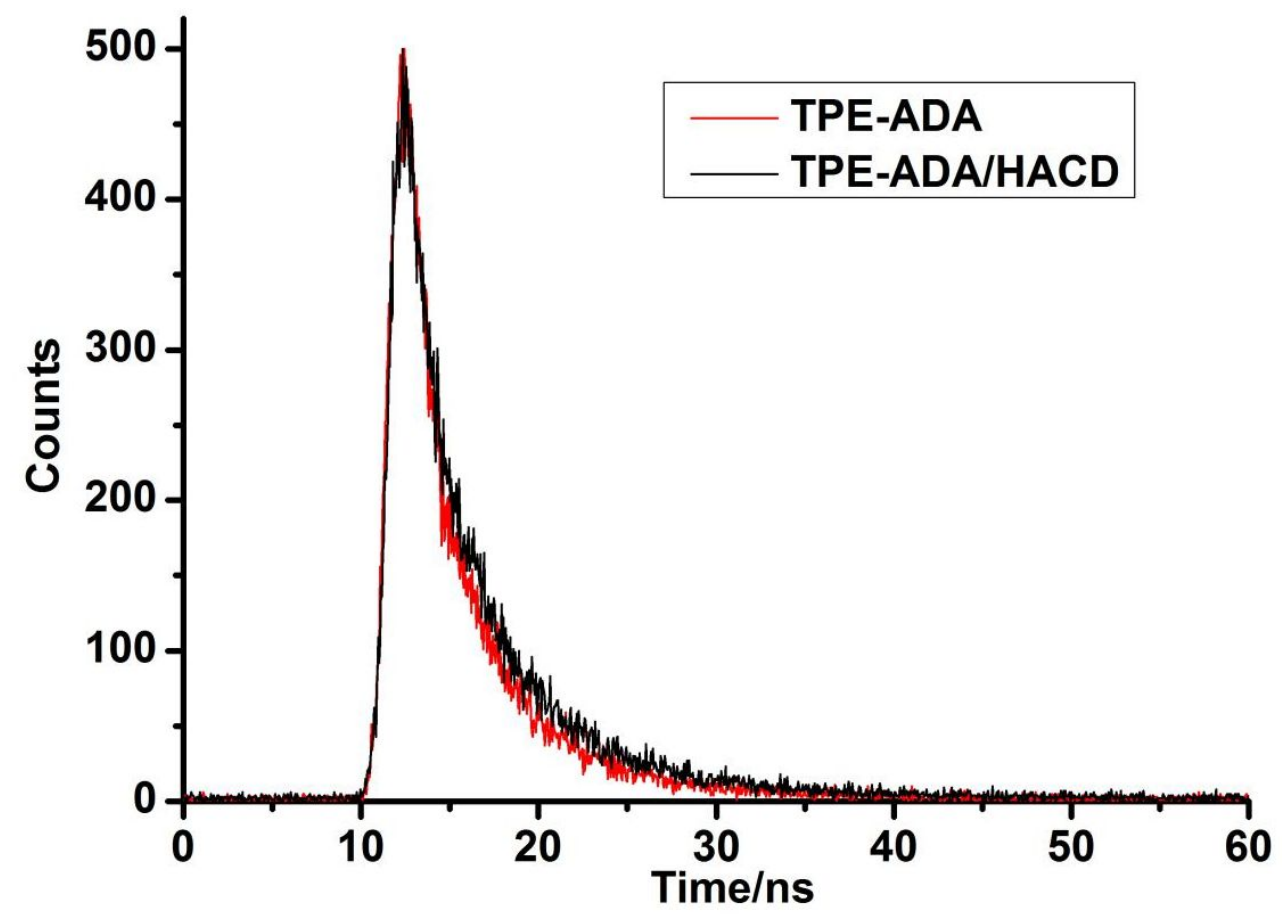

Figure S16. The fluorescence lifetime curves of TPE-ADA and TPE-ADA/HACD $\left(\lambda_{\mathrm{ex}}=330 \mathrm{~nm},[\right.$ TPE-ADA $]=3 \times 10^{-5} \mathrm{M},[\mathbf{H A C D}]=8.8 \times 10^{-7} \mathrm{M}$, containing $6 \times$ $10^{-5} \mathrm{M} \beta$-CD, solvent was aqueous solution containing $4 \% \mathrm{DMSO}$ at $25^{\circ} \mathrm{C}$ ).

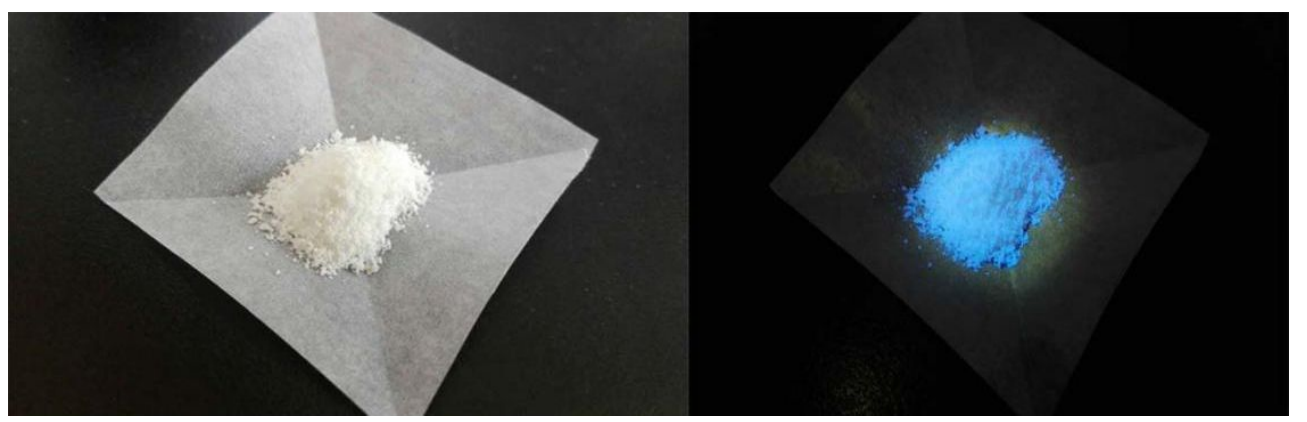

Figure S17. Fluorescence characterization of TPE-ADA in solid state under nature light and UV light (365 nm) separately. 


\section{Reference:}

[1] Yang, Y.; Zhang, Y.-M.; Chen, Y.; Chen, J.-T.; Liu, Y. Targeted Polysaccharide Nanoparticle for Adamplatin Prodrug Delivery. J. Med. Chem. 2013, 56, 9725-9736.

[2] Yu, Q.; Zhang, Y.-M.; Liu, Y.-H.; Xu, X.; Liu, Y. Magnetism and Photo Dual-Controlled Supramolecular Assembly for Suppression of Tumor Invasion and Metastasis. Sci. Adv. 2018, 4, eaat 2297. 